UDC 519.714: 622.7

Morkun V. S. ${ }^{1}$, Morkun N. V. ${ }^{2}$, Tron V. V. ${ }^{3}$

${ }^{1}$ Dr., Professor, Vice rector for research, Kryvyi Rih National University, Kryvyi Rih, Ukraine

${ }^{2} \mathrm{PhD}$, Associate Professor, Associate Professor of Economics Cybernetics and Projects Management Department, Kryvyi Rih National University, Kryvyi Rih, Ukraine

${ }^{3} \mathrm{PhD}$, Associate Professor, Associate Professor of Computer Science, Automation and Control Systems Department, Kryvyi Rih National University, Kryvyi Rih, Ukraine

\title{
AUTOMATIC CONTROL OF THE ORE SUSPENSION SOLID PHASE PARAMETERS USING HIGH-ENERGY ULTRASOUND
}

Context. The authors have solved the urgent problem of controlling automatically the parameters of solid ore suspension aimed for conversion thus increasing the end product quality and facilitating the choice and adhearance to the concentration specifications.

Objective. The research aims at developing the method of obtaining operational data as to iron ore characteristics while concentrating, namely distribution of solid pulp particles as to their sizes and estimated grade applying multi-channel ultrasonic measurements.

Method. In order to solve the problem of controlling automatically the parameters of solid ore suspension, the authors suggest the method of measuring the intensity of high-frequency bulk ultrasonic waves covering a fixed distance in a measuring chamber containing ore suspension under the influence of ultrasonic vibrations and in case of their absence. The calculated correlations of the measured values make it possible to determine the parameters of solid ore suspension. Besides, while measuring we can observe the formation of gamma-radiation and low-frequency bulk ultrasonic waves in the ore suspension flow. It is possible to measure the intensity of gamma-radiation and lowfrequency bulk ultrasonic waves covering the fixed distance if the measuring chamber contains some reference fluid and the ore suspension flow under ultrasonic vibrations and in the absence thereof. The intensity of ultrasonic vibrations influencing the suspension flow is changed according to the relevant law.

Results. The dynamic effects of high-frequency ultrasound provide a theoretical basis and a practical approval of the method controlling the solid phase of iron ore pulps in order to displace the particles of the required grain-size class to the measuring zone and to determine the grade in ore particles.

The developed purpose-designed programme realizes a numerical analysis and graphical representation of simulation results of changing solid pulp particle-sizes under the controlled influence of high-energy ultrasonic radiation pressure.

Conclusions. The authors have devised the method for controlling the distribution of the grade in crushed ore particle-size classes in the pulp flow by means of measuring the changes in the distribution parameters of high- and low-frequency ultrasonic waves as well as gamma-radiation. The method is different from the existing ones by the fact that in the course of measuring, the crushed ore particles of the required size and density are displaced to the measuring zone by exposing the pulps to the high-energy ultrasound influence thus increasing the measurement accuracy by $0.76 \%$.

Keywords: automatic control, ore, suspension, solid phase, particle size distribution, crushed ore, high energy ultrasound.

\section{NOMENCLATURE}

$\bar{E}$ is a time average energy density in the incident wave;

$\sigma_{s}$ is a effective cross sections of scattering;

$\sigma_{p}$ is a effective cross sections of absorption;

$I_{v}$ is a value of the scattered wave intensity at an angle $v$; $n_{r}(Z, t)$ is a the concentration of pulp solid phase particles; $R$ is a radius;

$Z$ is a coordinate $Z$ in ultrasonic field;

$T$ is a time;

$V_{r}(Z, t)$ is a particle displacement speed;

$I$ is a intensity of ultrasonic waves;

$v_{0}$ is a frequency of the sound;

$\alpha$ is a attenuation coefficient;

$n_{r}(Z, t)$ is a concentration of particles

$\rho_{\mathrm{T}}$, is a particle density;

$c_{\mathrm{T}}$ is a velocity of ultrasound in the material of particle;

$\rho$ is a density of investigated medium;

$c$ is a ultrasound velocity in investigated medium;

$\mu_{s}$ is a mass attenuation coefficients of suspension ore material;

$\mu_{\mathrm{w}}$ is a mass attenuation coefficients of water;

$\rho_{\mathrm{w}}$ is a density of water;

$\rho_{\mathrm{S}}$ is a density of suspension ore material particles;
$W$ is a volume fraction of ore particles in suspension;

$S(t)$ is the signal, which is generated;

$S_{\mathrm{B}}$ is the measured value $S$ in the presence of high intensity ultrasonic oscillations influence;

$S_{0}$ is the measured value $S$ in the absence of this influence;

$k_{1}$ is a proportionality coefficient.

\section{INTRODUCTION}

One of the most important parameters, which has a decisive influence on the qualitative and quantitative indicators of separation beneficiation technology is the degree of minerals disclosure at every stage of the process. For operational control of this parameter during the technological process it is proposed to use measurable redistribution of pulp solid phase particles under the influence of the dynamic effects of high-energy ultrasound.

Due to the radiation pressure of the high-energy ultrasound in the measurement zone there is a redistribution of crushed ore particles by size. At a constant pulp flow rate the characteristics of this redistribution are determined by the intensity of the ultrasound field and the concentration and the characteristics of the pulp solid phase.

Thus a method of ore suspension parameters automatic control allows to increase the stability and reliability of measurement results of ore suspension solid phase. 


\section{PROBLEM STATEMENT}

The object of the invention is to improve a method of ore suspension parameters automatic control by increasing the stability and reliability of measurement results.

The problem is solved by the fact that the method of automatic control of the ore suspension solid phase parameters, which comprising the forming of ore suspension material flow and the reference fluid in the measuring chamber, periodic influence of ultrasonic vibrations on suspension flow, formation of high frequency bulk ultrasonic waves in the ore suspension flow, intensity measurement of high frequency bulk ultrasonic waves, which are passed a fixed distance in the presence of reference liquid and ore suspension flow in the measuring chamber in periods of ultrasonic oscillations influence on suspension flow, and for its absence, and calculation of measured values ratios, according to which the parameters of ore suspension solid phase are determined.

\section{REVIEW OF THE LITERATURE}

Three types of controlled parameters, which characterizing respectively the quality and quantity of processed ore materials, and the production situations, the state of the technological equipment are necessary for effective concentrating factories process control $[2-4,7$, 11]. The known ultrasonic testing methods of the pulp parameters allow to identify two of its main characteristics density and particle size distribution $[2,3,8,10-13,16]$.

In $[1,12,15]$ several methods of ultrasonic testing of mineral disclosure degree (useful component) during ore grinding are proposed and investigated. It is noted that the mineral disclosure degree control with the known fineness of analyzed particle may be reduced to measuring of this particle density.

One of the proposed methods is based on the action of a powerful (high-energy) ultrasound on the particle during its motion. The strength of the radiation pressure on a particle in a plane wave is determined by the formula, which was obtained by Westervelt $[2,5]$

$$
F_{r}=\bar{E}\left(\sigma_{s}+\sigma_{p}\right)-\bar{E} \oint I_{v} \cos v d S .
$$

For estimation of particles displacement under the influence of high-intensity ultrasound the change in the value of ultrasonic probe signal with frequency $v$ in a direction perpendicular to the motion of pulp is determined. In [7] the ratio of two probe signal values was studied, one of which $S_{0}$ is determined without the influence of a powerful ultrasonic field, the other $S_{1}-$ with the presence. It is concluded that the density of the pulp solid phase particles can be determined by value of $\mathrm{S}_{1} / \mathrm{S}_{0}$.

However, this determination method has its disadvantages. First of all, it should be noted that the ultrasonic attenuation coefficient of the probe signal $\alpha$ depends on the volume fraction of solids in the pulp, therefore change of this value can have a greater effect than the change in particle density. Furthermore, the expression, which defining the value of $S_{1} / S_{0}$, is strong enough approximation, since it does not considers a number of factors, such as changes in particle size distribution law by a coefficient $\alpha$ etc. It should be noted that the use of high- intensity ultrasound of given intensity is a promising direction for a preliminary purposeful redistribution of crushed material particles in a controlled pulp flow at development of its parameters control systems.

The closest technical solution, which is selected as a prototype, is a method of automatic control of the ore suspension solid phase parameters [6]. The disadvantage of this method is that the Love waves intensity in the measuring chamber wall, which contacts with the controlled medium flow varies according to condition of the metal film on the measuring chamber wall, which is in constant contact with the ore suspension abrasive medium. Wear and removing of the metal film leads to ambiguity of measured values, which are determined according to the parameters of the ore suspension solid phase. Thus, the known method requires constant monitoring and determining the state of metal film on the wall of the measuring chamber, and in the existing production is impossible. This fact leads to errors and, consequently, reduces the stability and reliability of measurement results.

According to the invention, gamma radiation and low frequency bulk ultrasonic waves in the flow of ore material slurry is formed, the intensity of gamma radiation and lowfrequency bulk ultrasonic waves is measured.

\section{MATERIALS AND METHODS}

To solve the problem of the automatic control parameters of ore solid slurries is proposed the method, which consists in measuring the intensity of the high frequency bulk ultrasonic waves transmitted at a fixed distance in the measuring container during periods ore slurry flow to affect the suspension with ultrasonic vibrations and in their absence. In this case, the calculated ratio of the measured values allows to determine the parameters of the solid phase of the ore slurry. Also, during the measurement are formed gamma radiation and low-frequency bulk ultrasonic waves in the ore slurry flow and are measured the intensity gammaradiation and low-frequency bulk ultrasonic waves transmitted at a fixed distance in the presence of the reference fluid in the measuring chamber and the ore slurry flow during effect on the slurry flow with ultrasonic vibrations and in their absence. At the same time, the intensity of ultrasonic vibrations during their effect on the flow of suspension is changed under the relevant law [8-10].

Functional scheme of automation, designed according to the stated principle of operation, is shown in Fig. 1.

Scheme of automation control product processing industry (Fig. 1) consists of three circuits. The circuit 1 is designed to generate directed high-energy ultrasound and consists of elements: 1A - control device (BC); 1B switchgear (NS) of ultrasonic phased array. The contour 2 is designed for measurement of the pulp density on the basis of the ultrasonic signal to determine the concentration of ore particles in the pulp.

The circuit consists of the following elements: $2 \mathrm{~A}-$ transducer ultrasonic signal transmitter $(\mathrm{BE}) ; 2 \mathrm{~B}$ - indicating and recording secondary transducer of the ultrasonic signal (BIR); 2C - control device (BC); 2D - switchgear (NS) source of ultrasonic vibrations. Contour 3 is designed to measure the iron content in the ore particles on the basis of gamma radiation. The circuit consists of the following elements: $3 \mathrm{~A}-$ 
primary transducer of gamma-radiation signal (RE); $3 b-$ indicating and recording secondary transducer of ultrasonic signal (RIR); $3 \mathrm{~b}$ - control device (RC); 3G - switchgear (NS) source of ultrasonic vibrations.

The character of concentration and particle size distribution change in the field of high-energy ultrasound depends on the density of the particles themselves, the frequency and intensity of the incident radiation $[4,9,13$, $14,16]$. Let's estimate the influence of ultrasound radiation pressure to concentration change of particle with radius of

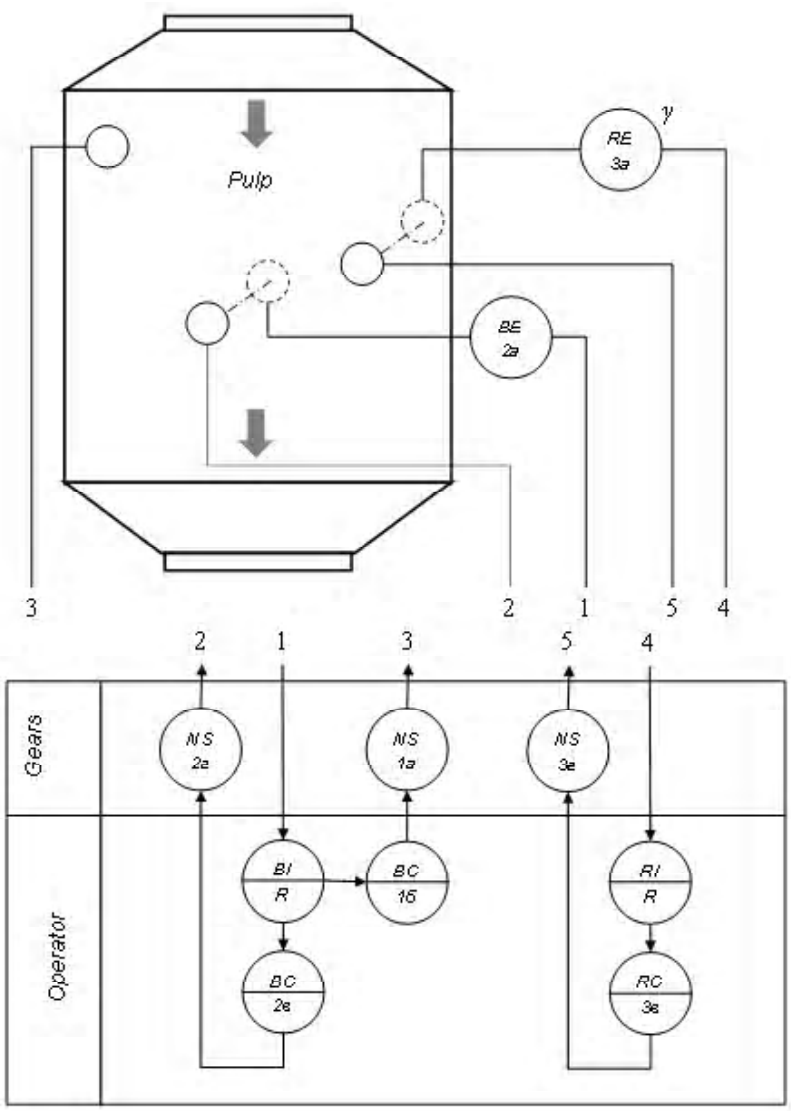

Figure 1 - Functional scheme of automation control product processing industry

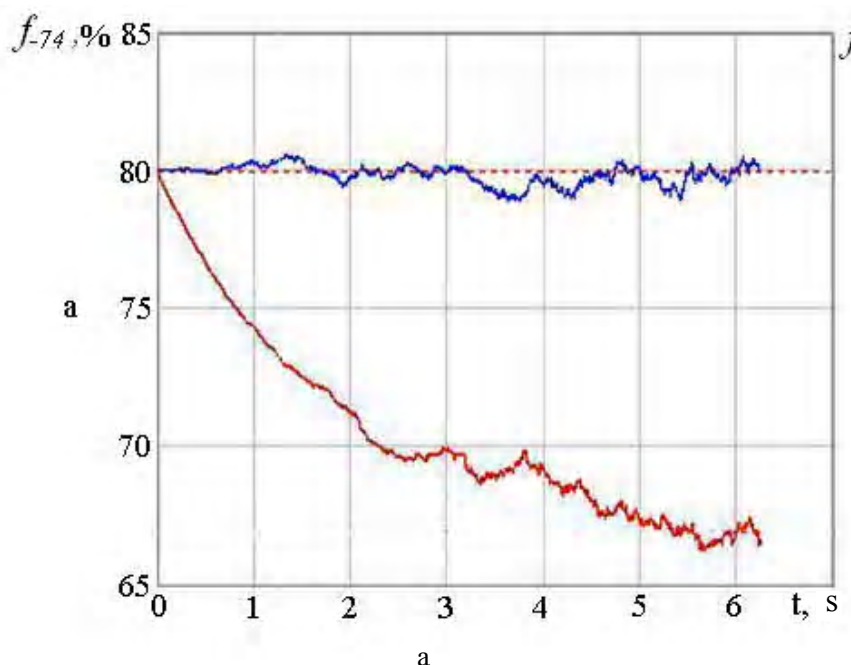

$r$ Suppose that in a positive direction of $x$-axis pulp flows at a rate of $V$. Let's denote by $n_{r}(Z, t)$ the concentration of the particle radius of $r$ at a depth of $Z$ at time $t$.

$$
\frac{\partial n_{r}(Z, t)}{\partial t}=-\frac{\partial}{\partial Z}\left[V_{r}(Z, t) n_{r}(Z, t)\right] \text {. }
$$

In this equation $V_{r}(Z, t)-$ is the particle displacement speed with radius $r$ and coordinate $Z$ in ultrasonic field. Speed is directed along the axis $z$, ie perpendicular to the flow of pulp. Generally, it depends on the time $t$, as the concentration of particles changes as a result of ultrasound action, and this leads to a change in the intensity of the ultrasound, which ultimately affects the particle displacement speed. However, this greatly complicates the solution of the equation (2), therefore we will assume that speed depends only on the coordinate $\mathrm{Z}$. Position of the particle in relative units is determined by the axis of ordinates, as well the number of its steps by the abscissa axis. Considering that the intensity of ultrasonic waves $I$ changes exponentially (initial value $I_{0}$ ), its attenuation coefficient $\alpha$ depends on the frequency of the sound $v_{0}$ and considering the analysis carried out in [7], the concentration of particles $n_{r}(Z, t)$ is determined by the formula

$$
\begin{gathered}
n_{r}(Z, t)=n_{0} \frac{e^{\alpha z}}{e^{\alpha z}-\alpha \beta t} \operatorname{St}\left(e^{\alpha z}-1-\alpha \beta t\right) . \\
S t(X)=\left\{\begin{array}{l}
0, X<0, \\
1, X \geq 0 ;
\end{array}\right. \\
\beta=\frac{2 r(k r)^{4}}{27 \eta c} I_{0}\left(a_{1}^{2}+a_{1} a_{2}+\frac{3}{4} a_{2}^{2}\right) ; €_{1}=1-\frac{\mathrm{rc}^{2}}{\rho \mathrm{c}^{2}} ; \\
\epsilon_{2}=2 \frac{\rho-\rho}{2 \rho+\rho} .
\end{gathered}
$$

Displacement of ore suspension solid particles leads to their redistribution by size and concentration in zone of high energy ultrasound influence (Fig. 2) [8-10].

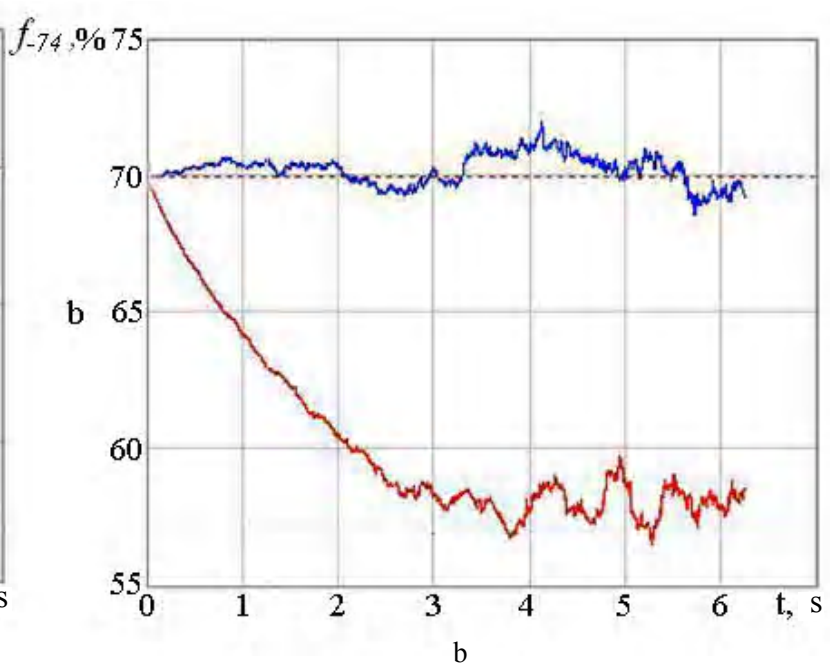

Figure 2 - The particle size measurement in controlled volume of pulp under the influence of the high-energy ultrasound radiation pressure: pulp density $-1250 \mathrm{~g} / \mathrm{l}$, the initial class content $-74 \mu \mathrm{m}-80 \%$ (a) and $70 \%$ (b) 
With increasing of high energy ultrasound intensity from zero to a certain value and at a constant pulp flow rate all or only certain crushed material size classes can be removed to the measurement zone. In the low-frequency region $\left(v \leq 10^{5} \mathrm{~Hz}\right)$ the ultrasonic attenuation caused mainly by viscous inertial losses, so $\sigma \approx \sigma_{v}$.

Consequently about the pulp density or solid phase content in it can be judged by the magnitude of the signal $\mathrm{S}_{1}$. In accordance with the above, we will control the value $S_{1}$ in measurement zone at each current moment of time. Then, with known law of change of high energy ultrasound intensity we will obtain the particle size distribution function of the crushed material in pulp flow.

\section{EXPERIMENTS}

The method is implemented as follows [8-10]. First, the reference liquid (water) is fed into the measuring chamber. Gamma radiation in the measuring chamber is formed, and passes a fixed distance in it. The obtained result is attenuation of the gamma radiation intensity. It is reference (basic). In operation condition, the ore material suspension flow in the measuring chamber is formed. Gamma radiation, which passes a fixed distance in the measurement chamber in the presence of ore material suspension flow is formed. The attenuation coefficient of gamma radiation, which passed a fixed distance in ore suspension material flow is determined by expression

$$
\mu=(1-W) \rho_{B} \mu_{B}+W \rho_{T} \mu_{T}
$$

The intensity of gamma radiation, which passed a distance $l$ in ore suspension material flow, can be presented as follows

$$
I=I_{0} \exp \left\{-\left[(1-W) \rho_{\mathrm{B}} \mu_{\mathrm{B}}+W \rho_{\mathrm{T}} \mu_{\mathrm{T}}\right] l\right\} \cdot
$$

If water is present in the measuring chamber then the intensity of gamma radiation will be determined by the formula

$$
I^{*}=I_{0} \exp \left(-\rho_{\mathrm{B}} \mu_{\mathrm{B}} l\right) .
$$

Considering (5) and (6), the intensity of gamma radiation can be represented as

$$
I=I^{*} \exp \left\{-W\left[\rho_{T} \mu_{T}-\rho_{B} \mu_{B}\right] l\right\} .
$$

This value does not depend on the particle size of solid phase ie ore slurry material, and determined only by the slurry solid phase concentration and its particles density. According to the proposed method the value $S_{r}$ for the gamma radiation is formed

$$
S_{\gamma}=\ln \frac{I^{*}}{I}=A W\left[\left(\rho_{T} \mu_{T}-\rho_{B} \mu_{B}\right) l\right] .
$$

This expression shows that the density of the controlled medium, which depends on the ore suspension solid phase concentration and its particle density is determined by logarithm of intensity ratio of the gamma radiation in the presence of water flow and ore suspension in measuring chamber. Similarly, the value $S_{1}$ is determined for high frequency and $S_{2}$ for low frequency bulk ultrasonic waves, which passed a fixed distance through the flow of water and ore suspension.
According to the proposed method the value $S_{r}$ is determined as

$$
S_{r}=k_{1} \frac{S_{B}-S_{0}}{S_{B}}
$$

To obtain a signal which depends on the useful component content of ore suspension solid phase fractions of corresponding size, ie disclosure of useful component, the ratio of $S_{K}$ is calculated

$$
S_{K}=k_{2} \frac{S_{\gamma}}{S_{r}}
$$

All or only certain size classes of the crushed material ie a certain solid phase size fraction can be displaced in the measurement zone by increasing the intensity of ultrasonic oscillations from zero to a certain value and with ore suspension constant flow rate.

$$
F(r)=\left(\int_{0}^{r_{1}} f(r) r^{3} d r+\int_{r_{1}}^{r_{2}} f(r) r^{3} d r+\ldots+\int_{r_{m-1}}^{r_{m}} f(r) r^{3} d r\right) / \int_{0}^{r_{m}} f(r) r^{3} d r .
$$

Thus, the value $S_{K}$, which is calculated at a certain ultrasonic oscillations intensity in the ore suspension flow determines the density of solid phase particles or useful component concentration in ore suspension solid phase fractions of appropriate size. Since all calculations are made on the basis of measurements relative to characteristics of the reference material, the obtained results are protected from various disturbing factors, which reduce the accuracy of measurement parameters of ore suspension solid phase.

\section{RESULTS}

Below are the simulation results of the crushed ore particles concentration redistribution in the pulp under the influence of high-energy ultrasound radiation pressure in accordance with the above expressions. The developed program realizes a numerical analysis and graphical representation of simulation results of changes in the pulp solid phase particle size characteristics in form, which is illustrated in Fig. 3.

The density of crushed ore particles may vary within a predetermined range (in model example $1.8-3.2 \mathrm{~g} / \mathrm{cm}^{3}$ is accepted). Geometry of measurement, source position and intensity of the ultrasonic oscillations, solid phase particles concentration and their size distribution are set before starting the simulation. The simulated measurement zone is represented by a segment of the pipeline, the length and the diameter of which may vary depending on the task and is directly correlated with the strength of the ultrasonic radiation pressure, which in turn is determined by the intensity of its radiation generated by the source (emitter).

The measuring range is a defined number of sections of the pipeline, in which the counting of number of particles, which are caught in them is carried out.

The y-axis (Fig. 3) shows the number of processed particles, moreover the deducible scale is automatically extended with an increase in simulation time, ie, the number of passed particles. 

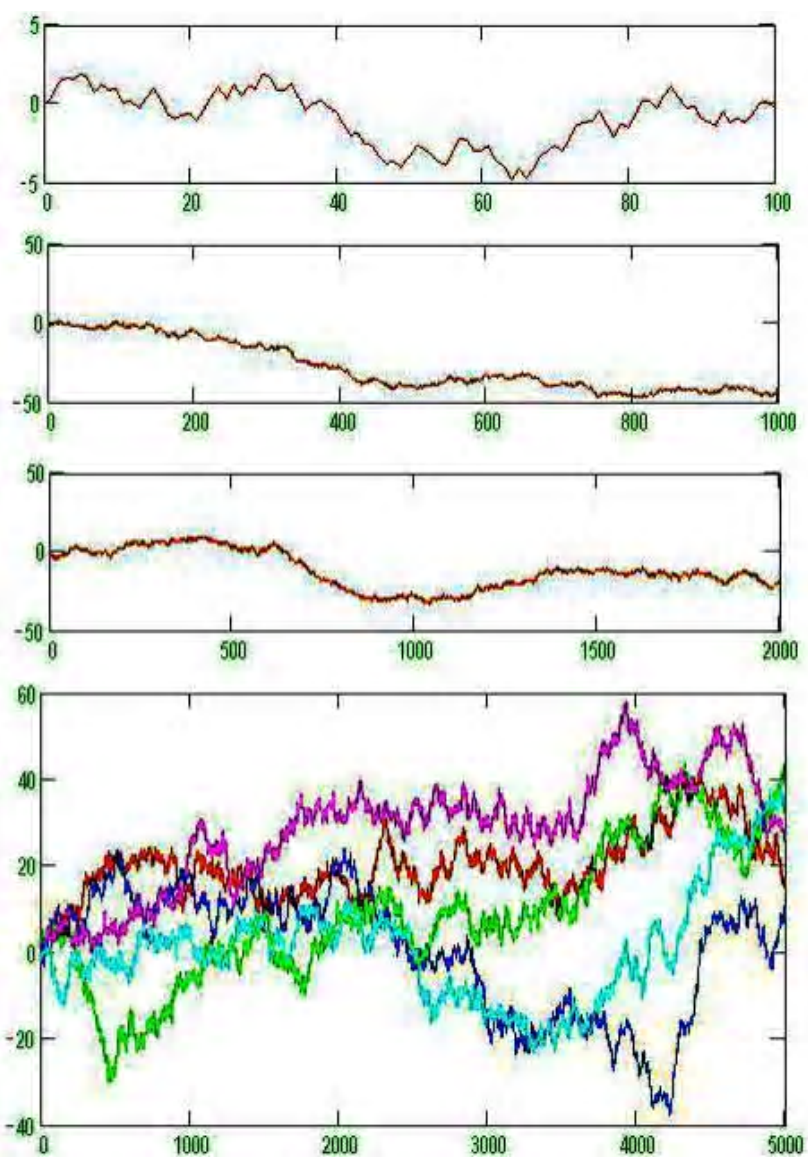

Figure 3 - The simulation results of ore particles coordinates change in the pulp with increasing of steps number

Figure 4 shows the simulation results at different time points, which demonstrates the independence of particles size distribution law on their number and simulation time.

\section{DISCUSSION}

Measurement of the useful component content can not be reduced to the determination of specific weight (density) of solid phase particles, which are located in the ore suspension. In the measuring chamber section, where the value $S$ is determined the flow of enriched material suspension is periodically exposed to high intensity ultrasonic waves. Due to the radiation pressure and acoustic flows, there is a displacement of ore suspension solid phase particles from the trajectory of their normal movement in the flow in the direction of high-intensity ultrasonic oscillations influence. Displacement of ore suspension solid phase particles leads to their redistribution by size and concentration in the high intensity ultrasonic oscillations influence zone. The value of this redistribution for the same particle size is determined only by the mineral composition (the ratio of the useful component and gangue) and specific weight (density) of each component. For solid phase particles of the same size, which are crushed to a particle size of useful component inclusions, the value of the displacement is proportional only to their specific weight.

Thus, the intensity measurement of high-frequency ultrasonic vibrations, which have passed through a controlled pulp volume, in the process of impact on it of high energy ultrasound with a given intensity allows to evaluate its solid phase particle size distribution.

\section{CONCLUSIONS}

Developed a method of evaluating the distribution function of the useful component by grade of particle size iron ore pulp using a high-frequency and low-frequency ultrasonic radiation and gamma radiation, which differs from existing ones that in the process of the measurement is carried out displacement of the particles of a given grade size in the measurement area by acting on the pulp with ultrasonic radiation of high intensity; the measurement results are compared with the reference substance characteristics, which improves the measurement accuracy by $0.76 \%$.

The proposed measurement method does not require preliminary pulp degassing, because under the ultrasound radiation pressure influence the gas bubbles are removed from the measurement zone. The invention relates to acoustic measurements and can be used for automatic control of the main characteristics of the ore solids in suspension, in particular the concentration of solids, its size distribution and the useful component disclosure degree.

\section{ACKNOWLEDGEMENTS}

The work is supported by the state budget scientific research project of Kryvyi Rih National University "The study of converting gamma rays, ultrasound body and surface waves on edges of heterophase environments for concentration technology optimization" (state registration number 0112U000359.30-88-12), "The study of dynamic effects of high-energy ultrasound on gas bubbles in the operating panel for controlling gas phase parameters during flotation" (state registration number № 0115U003031.30-100$15)$ and "Development of the method of determining mineraltechnological varieties of iron ore using microwave electromagnetic radiation, gamma radiation and high-energy ultrasound" (state registration number № 0115U003030.30101-15).

\section{REFERENCES}

1. Агранат Б. А. Физические основы технологических процессов, протекающих в жидкой фазе с воздействием ультразвука / Б. А. Агранат. - Москва : Машиностроение, 1969. - 266 с.

2. Бергман Л. Ультразвук и его применение в науке и технике / Л. Бергман. - Москва : Изд-во иностран. лит., 1957. - 726 с.

3. Гринман И. Г. Контроль и регулирование гранулометрического состава продуктов измельчения / И. Г. Гринман, Г. И. Блях. Алма-Ата : Наука, 1967. - 115 с.

4. Козин В. 3. Опробование, контроль и автоматизация обогатительных процессов / В. З. Козин, О. Н. Тихонов. - Москва : Недра, 1990. - 343 с.

5. Ландау Л. Д. Теоретическая физика. Механика сплошных сред / Л. Д. Ландау, Е. М. Лифшиц. - Москва : ГИТТЛ, 1954. $796 \mathrm{c}$.

6. Патент України на корисну модель. № 27086. UA. Спосіб автоматичного контролю параметрів твердої фази пульпи / Моркун В. С., Поркуян О. В. - Опубл. 10.10.2007. Бюл. № $16 .-3 \mathrm{c}$.

7. Morkun V. Simulation of the Lamb waves propagation on the plate which contacts with gas containing iron ore pulp in Waveform Revealer toolbox / V. Morkun, N. Morkun, A. Pikilnyak // Metallurgical and Mining Industry. - 2014. - № 5. - P. 16-19. 


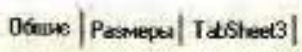
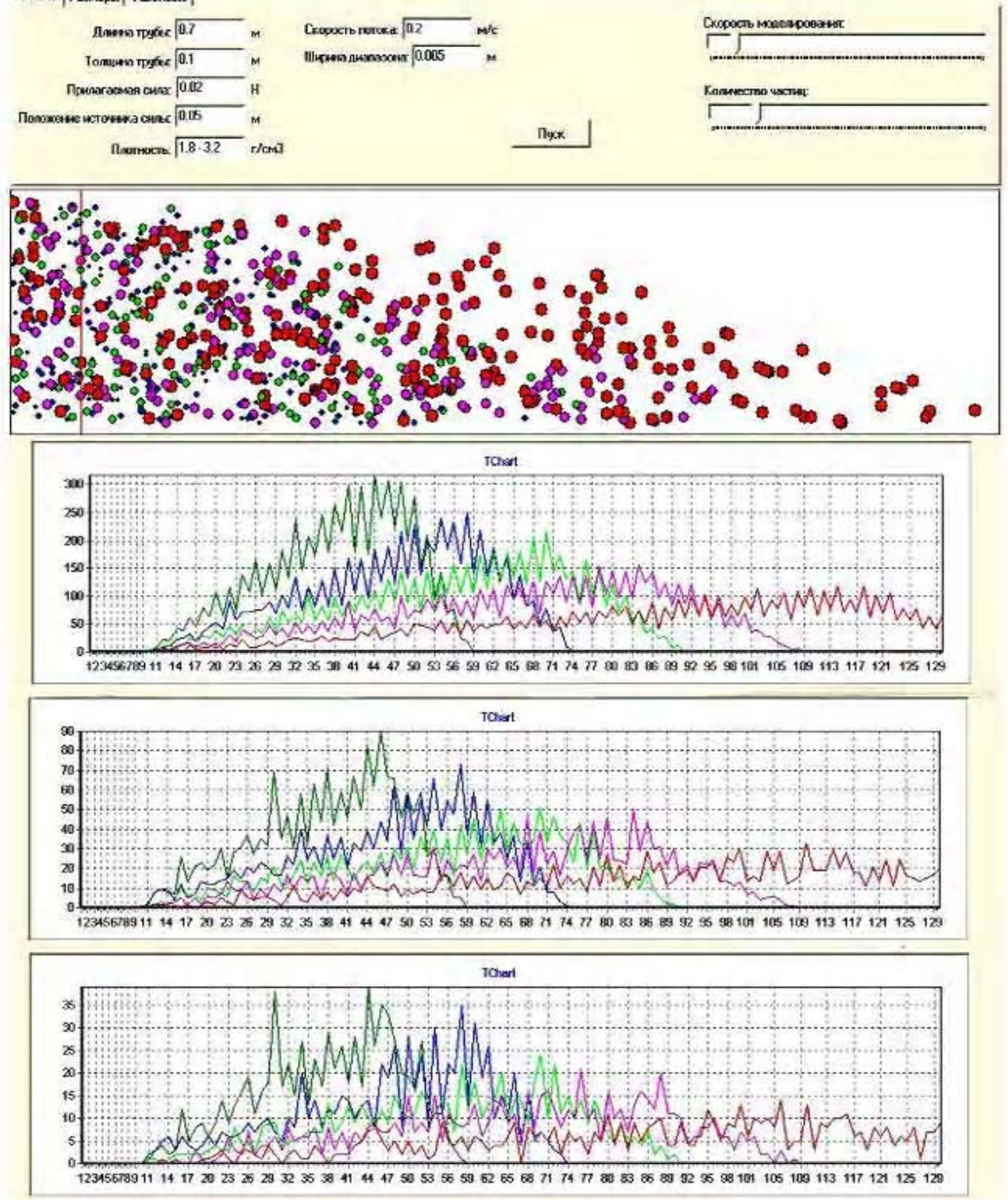

Figure 4 - The simulation results of redistribution of crushed ore particles concentration of five size fractions in the pulp flow under the influence of the high-energy ultrasound radiation pressure 
8. Morkun V. The adaptive control for intensity of ultrasonic influence on iron ore pulp / V. Morkun, N. Morkun, A. Pikilnyak // Metallurgical and Mining Industry. - 2014, - №. 6. - P. 8-11.

9. Morkun V. Formalization and frequency analysis of robust control of ore beneficiation technological processes under parametric uncertainty / V. Morkun, N. Morkun, V. Tron // Metallurgical and Mining Industry. - 2015. - №. 5. - P. 7-11.

10. Morkun V. Adaptive control system of ore beneficiation process based on Kaczmarz projection algorithm / V. Morkun, N. Morkun, A. Pikilnyak, // Metallurgical and Mining Industry. - 2015. № 2. - P. 35-38.

11. Назипов Р. А. Основы радиационного неразрушающего контроля / Р. А. Назипов, А. С. Храмов, Л. Д. Зарипова. - Казань : Изд-во Казанск. гос. ун-та, 2008. - 66 с.

12. Процуто В. С. Автоматизированные системы управления технологическими процессами обогатительных фабрик / В. С. Процуто. - Москва : Недра, 1987. - 253 с.
13. Физика и техника мощного ультразвука: [под ред. Л.Д. Розенберга, в 3 т]. - Москва : Наука. - 1967-1970.

14. Tabei M. A new k-space method for coupled first-order acoustic propagation equations / M. Tabei, T. D. Mast, R. C. Waag // Journal of the Acoustical Society of America (submitted). - 2001.

15. Трухан С. Н. Моделирование диффузии методом Монте-Карло / С. Н. Трухан. - Институт катализа им. Г. К. Борескова СО РАН. Режим доступа: http://www.exponenta.ru/educat/systemat/ truhan.

16. Wooh Shi-Chang Optimization of ultrasonic phased arrays / Wooh Shi-Chang, Shi Yijun // Review of Progress in Quantitative Nondestructive Evaluation. - 1998. - No. 17. - P. 883-890.

Article was submitted 17.01.2017. After revision 10.05.2017.

Моркун В. С. ${ }^{1}$, Моркун Н. В. ${ }^{2}$, Тронь В. В. ${ }^{3}$

'Д-р техн. наук, професор, проректор з наукової роботи, ДВНЗ «Криворізький національний університет», Кривий Ріг, Україна

${ }^{2}$ Канд. техн. наук, доцент, доцент кафедри економічної кібернетики та управління проектами, ДВНЗ «Криворізький національний університет», Кривий Ріг, Україна

${ }^{3}$ Канд. техн. наук, доцент, доцент кафедри інформатики, автоматики і систем управління, ДВНЗ «Криворізький національний університет», Кривий Ріг, Україна

АВТОМАТИЗОВАНЕ УПРАВЛІННЯ ПАРАМЕТРАМИ ТВЕРДОЇ ФАЗИ ЗАЛІЗОРУДНОЇ ПУЛЬПИ З ВИКОРИСТАННЯМ ВИСОКОЕНЕРГЕТИЧНОГО УЛЬТРАЗВУКУ

Актуальність. Вирішено актуальне завдання автоматичного контролю параметрів твердої фази рудної суспензії, що надходить на збагачувальний переділ. Це сприяє підвищенню якості кінцевого продукту і полегшує вибір і дотримання технологічного регламенту процесу збагачення.

Мета - розробка методу отримання оперативної інформації про характеристики залізної руди в процесі збагачення: розподіл часток твердої фази пульпи за крупністію і змістом корисного компонента з застосуванням багатоканальних ультразвукових вимірювань.

Метод. Для вирішення завдання автоматичного контролю параметрів твердої фази рудної суспензії запропонований спосіб, що полягає у вимірюванні інтенсивності високочастотних об'ємних ультразвукових хвиль, що пройшли фіксовану відстань в вимірювальній ємності з рудною суспензією в періоди впливу на потік суспензії ультразвукових коливань і при їх відсутності. При цьому отримані співвідношення виміряних величин дозволяють визначити параметри твердої фази рудної суспензії. Також, в процесі вимірювання здійснюється формування гамма-випромінювання і низькочастотних об'ємних ультразвукових хвиль в потоці суспензії рудного матеріалу, і здійснюють вимір інтенсивності гамма-випромінювання і низькочастотних об'ємних ультразвукових хвиль, що пройшли фіксовану відстань при наявності у вимірювальній камері еталонної рідини і потоку рудної суспензії в періоди впливу на потік суспензії ультразвукових коливань і при їх відсутності. Інтенсивність ультразвукових коливань в період їх впливу на потік суспензії змінюють за відповідним законом.

Результати. На основі динамічних ефектів високоенергетичного ультразвуку теоретично обгрунтований і експериментально апробований метод впливу на тверду фазу залізорудної пульпи для зміщення частинок певного класу крупності в зону вимірювань $\mathrm{i}$ визначення змісту корисного компонента в рудних частинках.

Розроблена спеціалізована програма, яка реалізує чисельний аналіз і графічне представлення результатів моделювання зміни гранулометричної характеристики твердої фази пульпи під керованим впливом радіаційного тиску високоенергетичного ультразвуку.

Висновки. Пропонується метод оцінки функції розподілу корисного компонента по класах крупності частинок подрібненої руди в потоці пульпи на основі вимірів параметрів процесу поширення високочастотних і низькочастотних ультразвукових хвиль, а також гамма-випромінювання, який відрізняється від існуючих тим, що в процесі вимірювань здійснюють зсув частинок подрібненої руди певної крупності і щільності в область вимірювань шляхом впливу на пульпу високоенергетичного ультразвуку, що дозволяє підвищити точність вимірювань на $0,76 \%$.

Ключові слова: автоматичне управління, руда, пульпа, тверда фаза, розподіл часток за розмірами, дроблення руди, високоенергетичний ультразвук.

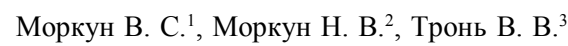

${ }^{1}$ Д-р техн. наук, профессор, проректор по научной работе, ГВУз «Криворожский национальный университет», Кривой Рог, Украина

${ }^{2}$ Канд. техн. наук, доцент, доцент кафедры экономической кибернетики и управления проектами, ГВУЗ «Криворожский национальный университет», Кривой Рог, Украина

${ }^{3}$ Канд. техн. наук, доцент, доцент кафедры информатики, автоматики и систем управления, ГВУЗ «Криворожский национальный университет», Кривой Рог, Украина

АВТОМАТИЗИРОВАННОЕ УПРАВЛЕНИЕ ПАРАМЕТРАМИ ТВЕРДОЙ ФАЗЫ ЖЕЛЕЗОРУДНОЙ ПУЛЬПЫ С ИСПОЛЬЗОВАНИЕМ ВЫСОКОЭНЕРГЕТИЧЕСКОГО УЛЬТРАЗВУКА

Актуальность. Решена актуальная задача автоматического контроля параметров твердой фазы рудной суспензии, поступающей на обогатительный передел, что способствует повышению качества конечного продукта и облегчает выбор и соблюдение технологического регламента процесса обогащения. 
Цель - разработка метода получения оперативной информации о характеристиках железной руды в процессе обогащения: распределение частиц твердой фазы пульпы по крупности и содержанию полезного компонента с применением многоканальных ультразвуковых измерений.

Метод. Для решения задачи автоматического контроля параметров твердой фазы рудной суспензии предложен способ, заключающийся в измерении интенсивности высокочастотных объемных ультразвуковых волн, прошедших фиксированное расстояние в измерительной емкости с рудной суспензией в периоды влияния на поток суспензии ультразвуковых колебаний и при их отсутствии. При этом вычисленные соотношения измеренных величин позволяют определить параметры твердой фазы рудной суспензии. Также, в процессе измерения осуществляется формирование гамма-излучения и низкочастотных объемных ультразвуковых волн в потоке суспензии рудного материала, и замер интенсивности гамма-излучения и низкочастотных объемных ультразвуковых волн, прошедших фиксированное расстояние при наличии в измерительной камере эталонной жидкости и потока рудной суспензии в периоды воздействия на поток суспензии ультразвуковых колебаний и при их отсутствии. Интенсивность ультразвуковых колебаний в период их влияния на поток суспензии меняют по соответствующему закону.

Результаты. На основе динамических эффектов высокоэнергетического ультразвука теоретически обоснован и экспериментально апробирован метод воздействия на твердую фазу железорудной пульпы для смещения частиц определенного класса крупности в зону измерений и определения содержания полезного компонента в рудных частицах.

Разработана специализированная программа, которая реализует численный анализ и графическое представление результатов моделирования изменения гранулометрической характеристики твёрдой фазы пульпы под управляемым воздействием радиационного давления высокоэнергетического ультразвука.

Выводы. Предлагается метод оценки функции распределения полезного компонента по классам крупности частиц измельчённой руды в потоке пульпы на основе измерений параметров процесса распространения высокочастотных и низкочастотных ультразвуковых волн, а также гамма-излучения, который отличается от существующих тем, что в процессе измерений осуществляют смещение частиц измельченной руды определенной крупности и плотности в область измерений путем воздействия на пульпу высокоэнергетическим ультразвуком, что позволяет повысить точность измерений на $0,76 \%$.

Ключевые слова: автоматическое управление, руда, пульпа, твердая фаза, распределение частиц по размерам, дробление руды, высокоэнергетический ультразвук.

\section{REFERENSES}

1. Agranat B.A. Fizicheskie osnovy tehnologicheskih processov, protekajushhih v zhidkoj faze s vozdejstviem ul'trazvuka. Moscow, Mashinostroenie, 1969, $266 \mathrm{p}$.

2. Bergman L. Ul'trazvuk i ego primenenie v nauke i tehnike. Moscow, Izd-vo inostran. lit., 1957, 726 p.

3. Grinman I. G., Bljah G. I. Kontrol' i regulirovanie granulometricheskogo sostava produktov izmel'chenija. AlmaAta, Nauka, 1967, 115 p.

4. Kozin V. Z., Tihonov O. N. Oprobovanie, kontrol' i avtomatizacija obogatitel'nyh processov. Moscow, Nedra, 1990, 343 p.

5. Landau L. D., Lifshic E. M. Teoreticheskaja fizika. Mehanika sploshnyh sred. Moscow, GITTL, 1954, 796 p.

6. Morkun V. S., Porkujan O. V. Patent Ukraïni na korisnu model'. № 27086. UA. Sposib avtomatichnogo kontrolju parametriv tverdoï fazi pul'pi/ Opubl. 10.10.2007. Bjul. № 16, 3 p.

7. Morkun V., Morkun N., Pikilnyak A. Simulation of the Lamb waves propagation on the plate which contacts with gas containing iron ore pulp in Waveform Revealer toolbox, Metallurgical and Mining Industry, 2014, No. 5, pp. 16-19.

8. Morkun V., Morkun N., Pikilnyak A. The adaptive control for intensity of ultrasonic influence on iron ore pulp, Metallurgical and Mining Industry, 2014, No. 6, pp. 8-11.
9. Morkun V., Morkun N., Tron V. Formalization and frequency analysis of robust control of ore beneficiation technological processes under parametric uncertainty, Metallurgical and Mining Industry, 2015, No. 5, pp. 7-11.

10. Morkun V., Morkun N., Pikilnyak A. Adaptive control system of ore beneficiation process based on Kaczmarz projection algorithm, Metallurgical and Mining Industry, 2015, No. 2, pp. 35-38.

11. Nazipov R. A., Hramov A. S., Zaripova L. D. Osnovy radiacionnogo nerazrushajushhego kontrolja. Kazan', Izd-vo Kazansk. gos. unta, 2008, $66 \mathrm{p}$.

12.Procuto V. S. Avtomatizirovannye sistemy upravlenija tehnologicheskimi processami obogatitel'nyh fabrik. Moscow, Nedra, 1987, $253 \mathrm{p}$.

13.Fizika i tehnika moshhnogo ul'trazvuka: [pod red. L. D. Rozenberga, v 3 t]. Moscow, Nauka, 1967-1970.

14.Tabei M., Mast T. D., Waag R. C. A new k-space method for coupled first-order acoustic propagation equations, Journal of the Acoustical Society of America (submitted), 2001.

15.Truhan S. N. Modelirovanie diffuzii metodom Monte-Karlo. Institut kataliza im. G. K. Boreskova SO RAN. Rezhim dostupa: http://www.exponenta.ru/educat/systemat/truhan.

16. Wooh Shi-Chang, Shi Yijun Optimization of ultrasonic phased arrays. Review of Progress in Quantitative Nondestructive Evaluation, 1998, No. 17, pp. 883-890. 